\title{
BIOMASS ACCUMULATION AND NUTRITION IN MICROPROPAGATED PLANTS OF THE BANANA 'PRATA CATARINA' UNDER BIOFERTILISERS ${ }^{1}$
}

\author{
EDER DE OLIVEIRA SANTOS ${ }^{2}$, THALES VINICIUS DE ARAÚJO VIANA ${ }^{3}$, GEOCLEBER GOMES DE SOUSA ${ }^{4}$, \\ ANA CRISTINA PORTUGAL PINTO DE CARVALHO ${ }^{5 *}$, BENITO MOREIRA DE AZEVEDO $^{3}$
}

\begin{abstract}
Banana farming is an activity of great economic and social importance, and is carried out in most tropical countries. The aim of this work was to evaluate the biomass accumulation and levels of nitrogen $(\mathrm{N})$, phosphorus $(\mathrm{P})$, potassium $(\mathrm{K})$, calcium $(\mathrm{Ca})$ and magnesium $(\mathrm{Mg})$ in micropropagated plants of the banana 'Prata Catarina' during the acclimatization phase, under different types and doses of biofertilisers. The experimental design included randomised blocks in a $2 \times 5+(2)$ factorial scheme, with two types of liquid biofertilisers (bovine biofertiliser with anaerobic and aerobic fermentation) and five biofertiliser doses $(0.25$, $0.50,0.75,1.00$, and $1.25 \mathrm{~L} \mathrm{plant}^{-1}$ week $^{-1}$ ), as well as two additional treatments (control and recommended mineral fertilisation). The following variables were analysed: dry weight of the leaves and roots, and mineral element content $(\mathrm{N}, \mathrm{P}, \mathrm{K}, \mathrm{Ca}$, and $\mathrm{Mg}$ ) in different parts of the plant (leaf and root). During 90 days of acclimatization, the nutritional contribution of bovine biofertiliser with anaerobic fermentation was greater in comparison with the biofertiliser with aerobic fermentation and the control, but lower in comparison with mineral fertilisation. The $1000-\mathrm{mL}$ dose of the biofertiliser with anaerobic fermentation promoted greater dry weight accumulation in the leaves and roots of the banana 'Prata Catarina'. The biofertiliser with anaerobic fermentation promoted higher levels of $\mathrm{N}, \mathrm{K}$, and $\mathrm{Ca}$ in the leaves, whereas the biofertiliser with aerobic fermentation promoted higher levels of $\mathrm{P}$ in the leaves and roots.
\end{abstract}

Keywords: Musa sp.. Organic input. Mineral elements.

\section{ACÚMULO DE BIOMASSA E NUTRIÇÃO DE MUDAS MICROPROPAGADAS DE BANANEIRA PRATA CATARINA ADUBADAS COM BIOFERTILIZANTES}

\begin{abstract}
RESUMO - A bananicultura destaca-se como uma atividade de grande importância econômica e social, sendo explorada na maioria dos países tropicais. O presente trabalho propôs avaliar o acúmulo de biomassa e os teores de nitrogênio $(\mathrm{N})$, fósforo $(\mathrm{P})$, potássio $(\mathrm{K})$, cálcio $(\mathrm{Ca})$ e magnésio $(\mathrm{Mg})$ em mudas micropropagadas de bananeira cv. Prata Catarina, durante a fase de aclimatização sob diferentes tipos doses e de biofertilizantes. O delineamento experimental foi em blocos casualizados em arranjo fatorial $2 \times 5+(2)$, referentes a dois tipos de biofertilizantes líquidos (bovino de fermentação anaeróbia e aeróbia) e cinco doses de biofertilizantes $(0,25$; 0,$50 ; 0,75 ; 1,00$ e $1,25 \mathrm{~L}_{\text {planta }}{ }^{-1}$ semana $^{-1}$ ), com dois tratamentos adicionais (controle e adubação mineral recomendada). Foram analisadas as seguintes variáveis: massa seca das folhas, das raízes e teores de elementos minerais (N, P, K, Ca e Mg) nas diferentes partes da planta (folha e raiz). O biofertilizante bovino com fermentação anaeróbia apresenta maior aporte nutricional em relação biofertilizante de fermentação aeróbio e ao controle, porém menor em relação à adubação mineral para as mudas durante os 90 dias de aclimatização. A dose de $1000 \mathrm{~mL}$ do biofertilizante com fermentação anaeróbia promove maior acúmulo de massa seca nas folhas e raízes da bananeira Prata Catarina. O biofertilizante com fermentação anaeróbia proporciona maiores teores de N, K e Ca nas folhas, enquanto, o biofertilizante com fermentação aeróbia promove maiores teores de $\mathrm{P}$ nas folhas e raízes.
\end{abstract}

Palavras-chaves: Musa sp.. Insumo orgânico. Elementos minerais.

\footnotetext{
*Corresponding author

${ }^{1}$ Received for publication in .08/09/2016; accepted in 03/06/2017.

Paper extracted from the master thesis of the first author.

${ }^{2}$ Department of Soil Science, Universidade Federal do Ceará, Fortaleza, CE, Brazil; ederolisan@gmail.com.

${ }^{3}$ Department of Agricultural Engineering, Universidade Federal do Ceará, Fortaleza, CE, Brazil; thales@ufc.br, benito@ufc.br.

${ }^{4}$ Institute of Rural Development, Universidade da Integração Internacional da Lusofonia Afro-Brasileira, Redenção, CE, Brazil; sousasolosgeo@hotmail.com.

${ }^{5}$ Plant Tissue Culture Laboratory, Embrapa Agroindústria Tropical, Fortaleza, CE, Brazil; cristina.carvalho@embrapa.br.
} 


\section{INTRODUCTION}

Banana (Musa spp.) production is an activity of notable economic and social importance, and is mostly practised by small farmers. With an annual production of 106 million tons, the banana ranks second in global fruit production. Brazil is the fifth highest producer of this fruit in the world, producing approximately 7.0 million tons annually (FAO, 2016).

The Northeast is the main banana-producing region in the country, especially the states of Bahia, Ceará, Pernambuco, and Rio Grande do Norte, where the production is mainly concentrated in the areas of irrigated fruit farming (SENA, 2011). Output from these states is almost entirely absorbed by the domestic market due to the importance of the fruit in the diet of the local population (GARRUTI et al., 2012).

The use of micropropagated plants in banana farming is being increasingly adopted in production systems, allowing rapid multiplication and uniformity of the crop (PEREIRA et al., 2010). The development of a commercial banana plantation from plants obtained with this technique makes it possible to increase the productivity, longevity, and profitability of the enterprise under both conventional and organic systems (MARTINS et al., 2011).

Using plants with desirable agronomic characteristics, along with organic components such as biofertilisers, which are liquid fertilisers produced in an aerobic or anaerobic environment from a mixture of organic material (manure) and water (SANTOS et al., 2014a), can reduce the maintenance costs of a banana plantation. It is an important alternative for supplying nutrients to the crops (VIANA et al., 2013) and consequently increasing their yield (SILVA et al., 2016).

Nutrient demand of a plant depends on its rate of growth and efficiency of biomass production from the absorbed nutrients (NOMURA et al., 2008). In decreasing order, the banana plant absorbs the following macronutrients: calcium $(\mathrm{Ca})>$ potassium $(\mathrm{K})>\operatorname{sulphur}(\mathrm{S})>$ magnesium $(\mathrm{Mg})>$ nitrogen (N) $>$ phosphorus (P) (MOREIRA; FAGERIA, 2009).

The aim of the present work was to evaluate biomass accumulation and the levels of $\mathrm{N}, \mathrm{P}, \mathrm{K}, \mathrm{Ca}$, and $\mathrm{Mg}$ in micropropagated plants of the banana 'Prata Catarina' during the acclimatization phase, under different types and doses of biofertilisers.

\section{MATERIAL AND METHODS}

The experiment was carried out from November 2014 to January 2015 in a controlled environment in the experimental area of the Federal University of Ceará $\left(03^{\circ} 44^{\prime} 44^{\prime \prime} \mathrm{S}, 38^{\circ} 32^{\prime} 50^{\prime \prime} \mathrm{W}\right)$, at an altitude of $19.6 \mathrm{~m}$. The climate of the region, according to the Köppen classification, is type "Aw": tropical rainy, with high temperatures and a predominantly rainy season in the autumn.

The treatments were distributed in a $2 \times 5+(2)$ factorial scheme, with two types of liquid biofertilisers (bovine biofertiliser with anaerobic and aerobic fermentation) and five doses of the biofertiliser $\quad(0.25, \quad 0.5, \quad 0.75, \quad 1.00, \quad$ and 1.25 L plant ${ }^{-1}$ week $^{-1}$ ), as well as two additional treatments (control and recommended mineral fertilisation as per Borges and Souza (2010)).

The experiment was conducted in 5-L black pots. The substrate used was coarse sand plus coarse vermiculite (1:1 ratio). The chemical composition of the substrate can be found in Table 1 .

Table 1. Chemical composition of the substrate used in the acclimatization of plants of the banana 'Prata Catarina', prior to application of the treatments.

\begin{tabular}{|c|c|c|c|c|c|c|c|c|}
\hline & \multicolumn{8}{|c|}{ Characteristic } \\
\hline $\mathrm{OM}$ & $\mathrm{N}$ & $\mathrm{P}$ & $\mathrm{K}^{+}$ & $\mathrm{Ca}^{2+}$ & $\mathrm{Mg}^{2+}$ & $\mathrm{Na}^{+}$ & $\mathrm{pH}$ & SD \\
\hline$\left(\mathrm{g} \mathrm{kg}^{-1}\right)$ & & - & $\mathrm{mmol}$ & - & & & $\mathrm{H}^{+}$ & $\mathrm{g} \mathrm{cm}^{-3}$ \\
\hline 0.31 & 0.26 & 0.30 & 0.27 & 18.00 & 16.80 & 6.67 & 7.2 & 1.3 \\
\hline
\end{tabular}

$\mathrm{OM}=$ Organic matter; $\mathrm{SD}=$ Substrate density

During the preparation of the biofertiliser with aerobic fermentation (B1), a 500-L polyethylene water tank was used, containing $200 \mathrm{~L}$ each of cattle manure and water (1:1 ratio). The mixture was allowed to ferment for 30 days (SANTOS et al., 2014a).

For the bovine biofertiliser with anaerobic fermentation (B2), $100 \mathrm{~L}$ each of cattle manure and water were used (1:1 ratio). The mixture was kept in 240-L plastic canisters, leaving an empty space of 15 to $20 \mathrm{~cm}$, which were then hermetically sealed. A hose was attached to the lid to enable gas to escape (CAVALCANTE et al., 2010). The nutrient content of the two biofertiliser types is shown in Table 2. 
Table 2. Composition of essential macronutrients and sodium $(\mathrm{Na})$ in the dry matter of aerobic and anaerobic biofertilisers.

\begin{tabular}{lcccccc}
\hline Biofertiliser & \multicolumn{7}{c}{ Nutrient $\left(\mathrm{g} \mathrm{L}^{-1}\right)$} \\
\hline & $\mathrm{N}$ & $\mathrm{P}$ & $\mathrm{K}$ & $\mathrm{Ca}$ & $\mathrm{Mg}$ & $\mathrm{Na}$ \\
\cline { 2 - 7 } & & 0.26 & 1.45 & 0.05 & 0.54 & 0.16 \\
\cline { 2 - 7 } Aerobic (B1) & 0.11 & 0.51 & 3.30 & 0.09 & 0.59 & 0.26 \\
\hline Anaerobic (B2) & 0.23 & 0.26
\end{tabular}

To meet the nutritional demands of micropropagated plants of the banana 'Prata Catarina' during the acclimatization phase, the maximum recommendation for chemical fertilisation as per Borges and Sousa (2010) was adopted, corresponding to $200 \mathrm{~kg} \mathrm{ha}^{-1}$ of N, $180 \mathrm{~kg} \mathrm{ha}^{-1}$ of $\mathrm{P}_{2} \mathrm{O}_{5--- \text {, }}$, and $450 \mathrm{~kg} \mathrm{ha}^{-1}$ of $\mathrm{K}_{2} \mathrm{O}$.

From the reference for a stand of 5,000 plants (at a spacing of $0.4 \times 0.5 \mathrm{~m}$ ), the maximum recommended dose per plant was calculated as $10.0 \mathrm{~g} \mathrm{~N}, 9.0 \mathrm{~g} \mathrm{P}_{2} \mathrm{O}_{5 \text {-, }}$ and $22.5 \mathrm{~g} \mathrm{~K}_{2} \mathrm{O}$. According to Table 1 , the substrate provided only $0.26,0.30$, and $0.27 \mathrm{~g} \mathrm{~kg}^{-1}$ of $\mathrm{N}, \mathrm{P}$, and $\mathrm{K}$, respectively.

Multiplying the volume of substrate in a pot ( $5 \mathrm{~L})$ by the density of the substrate $\left(1.30 \mathrm{~g} \mathrm{~kg}^{-1}\right)$, a value of $6.5 \mathrm{~g} \mathrm{~kg}^{-1}$ was obtained, i.e. the total $\mathrm{N}, \mathrm{P}$ and $\mathrm{K}$ available to the plants before application of the treatments was $1.56,1.95$, and $1.75 \mathrm{~g} \mathrm{~kg}^{-1}$, respectively. Therefore, there was a need for nutritional supplementation of $\mathrm{N}=8.44, \mathrm{P}=7.05$, and $\mathrm{K}=12.85 \mathrm{~g} \mathrm{plant}^{-1}$.

The biofertilisers were manually supplied in 10 doses. The banana 'Prata Catarina' plants were obtained using in vitro cultivation, and produced by a process of micropropagation, from a culture of the sucker shoot-tip (CARVALHO; RODRIGUES; SANTOS, 2012).

After this procedure, they were taken to the greenhouse, planted in the pots containing substrate, and moistened with nutrient solution. The solution contained half the concentration of macro- and micronutrients found in the MS culture medium (MURASHIGE; SKOOG, 1962) (Table 3). For 28 days, $3.0 \mathrm{~mL}$ of the solution was applied once a week spraying, to ensure the nutritional balance in the growing plants. This procedure was continued until the beginning of the individual treatments.

After 90 days of acclimatization, the leaves and roots were removed, placed inside paper bags labelled with the treatment type, and kept in an air-circulation oven at a temperature of $60{ }^{\circ} \mathrm{C}$. After 72 hours, the dry weight of the different parts of the plant (leaf and root) was determined.

The oven-dried samples were ground in a Wiley-type mill and the $\mathrm{N}$ content was determined from extracts prepared by sulphuric digestion, according to the micro-Kjeldahl method (TEDESCO et al., 1995). The K content was determined by flame photometry, the $\mathrm{P}$ content by photocolorimetry, and $\mathrm{Ca}$ and $\mathrm{Mg}$ by atomic absorption (MALAVOLTA, 2006). The results were subjected to ANOVA with significance at $5 \%$ probability and regression analysis. The mean values were compared by Tukey's test at $\mathrm{P}<0.05$, using the SISVAR software (FERREIRA, 2014).

\section{RESULTS AND DISCUSSION}

It can be seen from Table 4 that there was a significant interaction between dose and biofertiliser type for the leaf dry weight (LDW) and root dry weight (RDW), whereas the type of biofertiliser and dose separately had a significant effect only on LDW.

For the agronomic characteristics under evaluation, there was a significant interaction between dose and biofertiliser type only for $\mathrm{N}$ in the leaves and $\mathrm{P}$ in the roots. However, there was an isolated effect of dose on leaf dry weight (LDW) and for leaf N, P, and K content. There was an effect of the biofertiliser type on LDW and $\mathrm{N}$ in the leaves and roots, and on $\mathrm{K}$ in the roots.

The value for LDW was $2.73 \mathrm{~g}$ in the control and $7.27 \mathrm{~g}$ under mineral fertilisation. In Figure 1, a quadratic polynomial model can be seen for leaf dry weight in micropropagated plants of the banana 'Prata Catarina' fertilised with B1, reaching the maximum value of LDW (7.20 g) at an estimated dose of $784 \mathrm{~L}_{\text {plant }}{ }^{-1}$ week $^{-1}$. With B2, on the other hand, the best fit was a linear model with a positive slope.

The treatment with mineral fertiliser was better than the treatments with biofertiliser, despite the fact that values of the evaluated variables under the latter treatments approached those obtained with the conventional fertiliser.

Similarly, Chiconato et al. (2013) had found that the use of low doses of bovine biofertiliser with anaerobic fermentation did not favour development in lettuce, whereas at higher doses, it equalled or exceeded the performance of mineral fertiliser.

Baldotto et al. (2009) state that the application of organic compounds promoted vegetative growth in cultured plants of pineapple 'Vitória' during the acclimatization phase. Nomura et al. (2012) found that at 98 days after transplanting, the micropropagated plants of the banana 'Grand Naine' accumulated greater shoot dry biomass at a dose of $4.0 \mathrm{~mL}$ plant $^{-1}$ of the commercial biofertilisers HUMITEC $^{\circledR}$ and RUTER AA ${ }^{\circledR}(15.1 \mathrm{~g})$. 
Table 3. Concentrations of the nutrients that make up the MS culture medium applied to the micropropagated plants of the banana 'Prata Catarina'.

\begin{tabular}{|c|c|c|}
\hline Component & Formula & Concentration $\left(\mathrm{mg} \mathrm{L}^{-1}\right)$ \\
\hline \multicolumn{3}{|l|}{ Macronutrients } \\
\hline Ammonium nitrate & $\mathrm{NH}_{4} \mathrm{NO}_{3}$ & 1650 \\
\hline Potassium nitrate & $\mathrm{KNO}_{3}$ & 1900 \\
\hline Calcium chloride & $\mathrm{CaCl}_{2} \cdot 2 \mathrm{H}_{2} \mathrm{O}$ & 440 \\
\hline Magnesium sulphate & $\mathrm{MgSO}_{4} \cdot 7 \mathrm{H}_{2} \mathrm{O}$ & 370 \\
\hline Potassium phosphate & $\mathrm{KH}_{2} \mathrm{PO}_{4}$ & 170 \\
\hline \multicolumn{3}{|l|}{ Micronutrients } \\
\hline Potassium iodide & KI & 0.83 \\
\hline Manganese sulphate & $\mathrm{MnSO}_{4} \cdot \mathrm{H}_{2} \mathrm{O}$ & 16.9 \\
\hline Zinc sulphate & $\mathrm{ZnSO}_{4} \cdot 7 \mathrm{H}_{2} \mathrm{O}$ & 8.6 \\
\hline Boric acid & $\mathrm{H}_{3} \mathrm{BO}_{3}$ & 6.2 \\
\hline Sodium molybdate & $\mathrm{Na}_{2} \mathrm{MoO} 4.2 \mathrm{H}_{2} \mathrm{O}$ & 0.25 \\
\hline Cobalt chloride & $\mathrm{CoCl}_{2} \cdot 6 \mathrm{H}_{2} \mathrm{O}$ & 0.025 \\
\hline Copper sulphate & $\mathrm{CuSO}_{4} .5 \mathrm{H}_{2} \mathrm{O}$ & 0.025 \\
\hline \multicolumn{3}{|l|}{ FeEDTA } \\
\hline Sodium EDTA & $\mathrm{Na}_{2}$ EDTA & 37.30 \\
\hline Iron sulphate & $\mathrm{FeSO}_{4} .7 \mathrm{H}_{2} \mathrm{O}$ & 27.80 \\
\hline \multicolumn{3}{|l|}{ Vitamins } \\
\hline Nicotinic acid & $\mathrm{C}_{6} \mathrm{H}_{5} \mathrm{NO}_{2}$ & 0.5 \\
\hline Pyridoxine hydrochloride & $\mathrm{C}_{6} \mathrm{H}_{12} \mathrm{CINO}_{2}$ & 0.5 \\
\hline Thiamine hydrochloride & $\mathrm{C}_{12} \mathrm{H}_{18} \mathrm{CL}_{2} \mathrm{~N}_{4} \mathrm{OS}$ & 0.1 \\
\hline Glycine & $\mathrm{C}_{2} \mathrm{H}_{5} \mathrm{NO}_{2}$ & 2.0 \\
\hline Myo-inositol & $\mathrm{C}_{6} \mathrm{H}_{12} \mathrm{O}_{6}$ & 100 \\
\hline
\end{tabular}

Table 4. Summary of ANOVA for leaf dry weight (LDW) and root dry weight (RDW) in micropropagated plants of the banana 'Prata Catarina' for dose and type of biofertiliser.

\begin{tabular}{cccc}
\hline SV & DF & \multicolumn{2}{c}{ Biomass } \\
\cline { 3 - 4 } & & Leaf & Root \\
\cline { 3 - 4 } Biofertiliser & 1 & $13.73^{* *}$ & $3.29 \mathrm{~ns}$ \\
Dose & 4 & $7.24^{* *}$ & $6.32 \mathrm{~ns}$ \\
Bio x Dose & 4 & $1.96^{* *}$ & $1.99^{* *}$ \\
Bio x ADC+Ctrl & 1 & $4.38^{* *}$ & $0.00^{* *}$ \\
ADC x Ctrl & 1 & $51.57^{* *}$ & $15.73^{*}$ \\
Treatments & 11 & $112.13^{* *}$ & $11.77^{* *}$ \\
Residual & 48 & 0.96 & 1.61 \\
Total & 59 & - & - \\
\hline CV & & 17.51 & 24.74 \\
\hline
\end{tabular}

$\mathrm{SV}=$ Source of variation; $\mathrm{DF}=$ Degrees of freedom; $*$ Significant by F-test at $5 \%$;**Significant by F-test at 1\%; ns: not significant; Bio $=$ Biofertiliser; $\mathrm{ADC}=$ Additional; $\mathrm{Ctrl}=\mathrm{Control} ; \mathrm{CV}=$ Coefficient of variation. 


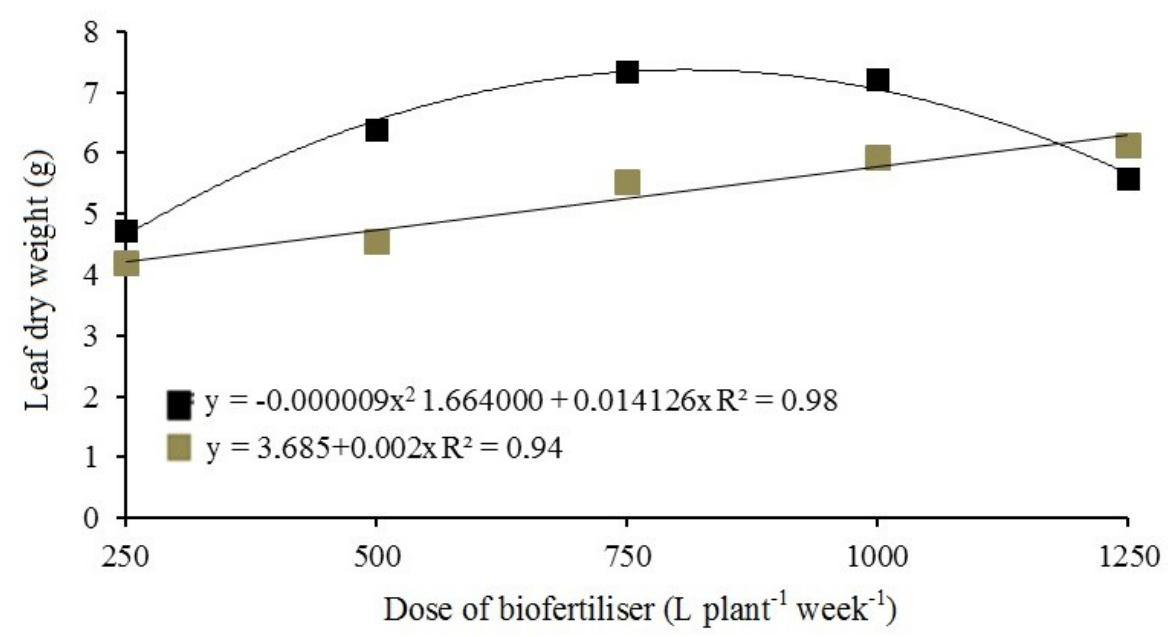

Figure 1. Leaf dry weight in micropropagated plants of the banana 'Prata Catarina' under application of aerobic ( $\square)$ and anaerobic ( $\square)$ biofertilisers.

The superiority of the biofertiliser with anaerobic fermentation with respect to the one with aerobic fermentation is in the quantities of essential elements (Table 2), i.e., anaerobic fermentation likely improves the availability of these nutrients in the study substrate. This is reflected in the results of Baalousha, Heino and Coustumer (2006), who showed that such fermentation might cause an increase in the osmotic adjustment of plants via accumulation of organic solutes, promoting the absorption of water and nutrients.

The value for RDW was $3.88 \mathrm{~g}$ in the control and $6.38 \mathrm{~g}$ under mineral fertilisation. With the variable RDW, the quadratic polynomial model proved to be the best for the anaerobic biofertiliser (B2). The estimated RDW was $6.3 \mathrm{~g}$ for a $785 \mathrm{~L}_{\text {plant }}{ }^{-1}$ week $^{-1}$ dose of bovine biofertiliser. For the aerobic bovine biofertiliser (B1), the increasing linear model gave the best fit (Figure 2).

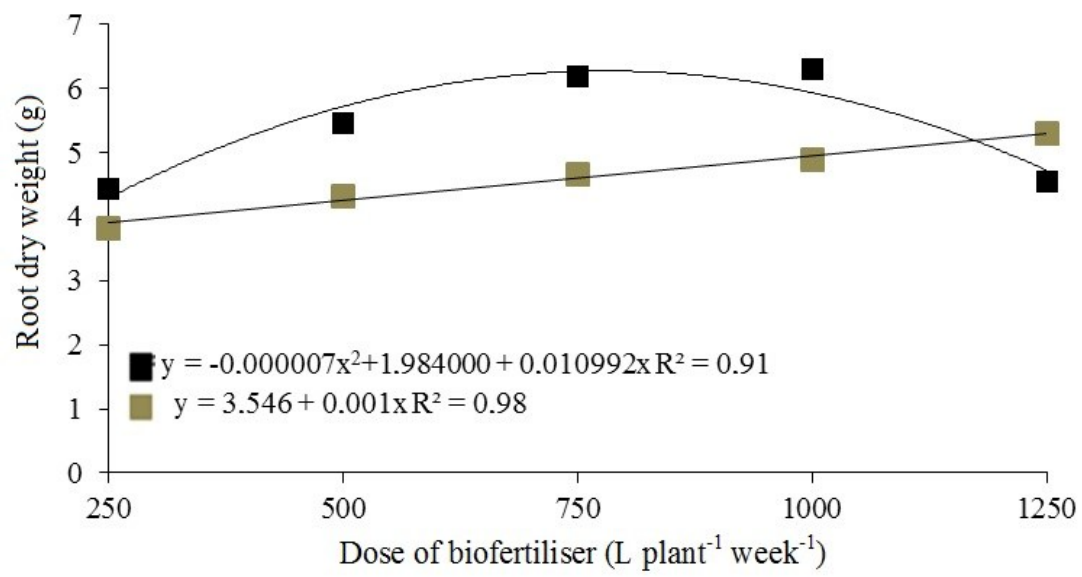

Figure 2. Root dry weight in micropropagated plants of the banana 'Prata Catarina' for the aerobic $(\square)$ and anaerobic biofertilisers.

These results corroborate those of Viana et al. (2013), demonstrating that the biofertiliser application can strengthen the root system of the plants and promote the absorption of water and nutrients. Lima, Bellicanta and Moraes (2006) also obtained similar results for the biomass accumulation in the root system of micropropagated plants of the banana 'Nanicão' fertilised with liquid organic fertiliser.

The results can be explained by the more paste-like nature of anaerobic biofertiliser, leading to a gradual release of nutrients, meeting the requirements of the plants and providing adequate nutrition. The nutrients from organic matter, which are present in cattle manure, might remain immobilised in the soil after incorporation; however, they are released in increasingly high amounts after about a month (SAMPAIO; OLIVEIRA; NASCIMENTO, 2007). 
It can be seen from Table 5 that there was a significant interaction between dose and biofertiliser type for $\mathrm{N}, \mathrm{K}, \mathrm{Ca}$, and $\mathrm{Mg}$ in the leaves and for $\mathrm{P}$, $\mathrm{Ca}$, and $\mathrm{Mg}$ in the roots. However, there was an isolated effect of dose on the $\mathrm{N}, \mathrm{P}, \mathrm{Ca}$, and $\mathrm{Mg}$ foliar contents, and of the biofertiliser type on the leaves, where there was a positive effect for all nutrients, and root, where only $\mathrm{K}, \mathrm{Ca}$, and $\mathrm{Mg}$ were not significant.

Table 5. Summary of ANOVA for leaf and root N, P, K, Ca, and Mg content in micropropagated plants of the banana 'Prata Catarina' for dose and type of biofertiliser.

\begin{tabular}{|c|c|c|c|c|c|c|c|c|}
\hline SV & $\mathrm{B}$ & $\mathrm{D}$ & $\mathrm{B} \times \mathrm{D}$ & Fat $x$ ADC & $\mathrm{ADC}$ & Residual & Total & CV (\%) \\
\hline DF & 1 & 4 & 4 & 1 & 1 & 48 & 59 & \\
\hline & \multicolumn{8}{|c|}{$\begin{array}{c}\text { Nutrient } \\
\text { (Nitrogen) }\end{array}$} \\
\hline Leaf & $222.18^{* *}$ & $87.86^{* *}$ & $9.00 * *$ & $27.39 * *$ & $706.44 * *$ & 1.43 & - & 4.76 \\
\hline \multirow[t]{2}{*}{ Root } & $41.26 * *$ & $6.81 * *$ & $0.50 \mathrm{~ns}$ & $0.85 \mathrm{~ns}$ & $69.17 * *$ & 0.39 & - & 6.85 \\
\hline & \multicolumn{8}{|c|}{ (Phosphorus) } \\
\hline Leaf & $2.47 * *$ & $0.54 *$ & $0.22 \mathrm{~ns}$ & $0.32 \mathrm{~ns}$ & $1.83 * *$ & 0.19 & - & 14 \\
\hline \multirow[t]{2}{*}{ Root } & $0.41 * *$ & $2.05 * *$ & $0.18 *$ & $12.09 * *$ & $0.11 \mathrm{~ns}$ & 0.05 & - & 9.59 \\
\hline & \multicolumn{8}{|c|}{ (Potassium) } \\
\hline Leaf & $457.83 * *$ & $16.87 \mathrm{~ns}$ & $13.12^{* *}$ & $229.86^{* *}$ & $118.34 *$ & 24.36 & - & 12.82 \\
\hline \multirow[t]{2}{*}{ Root } & $36.89 \mathrm{~ns}$ & $159.73 * *$ & $67.17 \mathrm{~ns}$ & $3253.81 * *$ & $1353.73 * *$ & 26.55 & - & 14.81 \\
\hline & \multicolumn{8}{|c|}{ (Calcium) } \\
\hline Leaf & $46.74 * *$ & $14.66^{*}$ & $3.88^{*}$ & $0.25 \mathrm{~ns}$ & $5.59 * *$ & 0.52 & - & 4.67 \\
\hline \multirow[t]{2}{*}{ Root } & $0.32 \mathrm{~ns}$ & $3.33 \mathrm{~ns}$ & $9.25^{* *}$ & $40.82 * *$ & $49.99 * *$ & 1.61 & - & 8.20 \\
\hline & \multicolumn{8}{|c|}{ (Magnesium) } \\
\hline Leaf & $0.99 * *$ & $0.05^{* *}$ & $0.07 * *$ & $0.03 \mathrm{~ns}$ & $1.19 * *$ & 0.05 & - & 5.56 \\
\hline Root & $0.03 \mathrm{~ns}$ & $0.08 \mathrm{~ns}$ & $0.16^{*}$ & $0.45^{* *}$ & $2.01 * *$ & 0.05 & - & 10.66 \\
\hline
\end{tabular}

$\mathrm{SV}=$ Source of variation; $\mathrm{DF}=$ Degree of freedom; *Significant by F-test at $5 \%$; * Significant by F-test at $1 \%$; ns: not significant; $\mathrm{B}=$ Biofertiliser; $\mathrm{D}=$ Dose; Fat $=$ Factorial; $\mathrm{ADC}=$ Additional; $\mathrm{CV}=$ Coefficient of variation.

The value of $\mathrm{N}$ in the leaves was $15.2 \mathrm{~g} \mathrm{~kg}^{-1}$ in the control treatment and $32.01 \mathrm{~g} \mathrm{~kg}^{-1}$ under mineral fertilisation, whereas, in the roots, it was $11.45 \mathrm{~g} \mathrm{~kg}^{-1}$ under mineral fertilisation and $6.19 \mathrm{~g} \mathrm{~kg}^{-1}$ in the control.

Hoffmann et al. (2010), irrigating banana plants via fertigation with mineral fertilisers, found that $\mathrm{N}$ was the second most-accumulated macronutrient in the plants, while, for the leaves, this accumulation was seen in the Dwarf Prata and Grande Naine cultivars.

The leaf $\mathrm{N}$ content displayed a linear increase with the biofertiliser dose (Figure 3a). This result might be related to the type of fermentation and the amount of $\mathrm{N}$, as presented in Table 2 . The values for $\mathrm{N}$ present in the leaves with both aerobic and anaerobic biofertilisers are below the range considered suitable for leaves of the banana plant (MOREIRA; FAGERIA, 2009), where a value of $24.02 \mathrm{~g} \mathrm{~kg}^{-1}$ is considered satisfactory.

Similarly, Moreira and Fageria (2009), analysing the effect of organic fertilisation using biofertiliser with aerobic fermentation in leaves of the banana 'Pacovan', recorded values lower than those of this study (18.09 $\mathrm{g}_{\text {leaf }} \mathrm{N} \mathrm{kg}^{-1}$ ). However, Viana et al. (2013), analysing the effect of organic fertilisation using bovine and mixed biofertiliser with aerobic fermentation on the leaves of melon plants, recorded values greater than those in this study ( $\left.35.00 \mathrm{~g}_{\text {leaf }} \mathrm{N} \mathrm{kg}^{-1}\right)$. In addition, Cavalcante et al. (2010), working under field conditions, found an increase in the $\mathrm{N}$ concentrations in okra plants fertilised with goat, cattle, and chicken manure as an organic source.

From the results of the mean-values test, presented in Figure 3b, it can be seen that the levels of $\mathrm{N}$ in the roots differ by Tukey's test $(\mathrm{p}>0.05)$ in plants grown under the two different types of biofertiliser, with anaerobic fermentation (10.04 $\left.\mathrm{g} \mathrm{kg}^{-1}\right)$ being superior to aerobic fermentation $\left(8.22 \mathrm{~g} \mathrm{~kg}^{-1}\right)$.

This superiority might be related to the types 
of microorganisms acting in the absence of oxygen or in the plant metabolism of the cattle feed, where the presence of L-glutamic acid participates in the process of nitrogen assimilation and in the synthesis and activation of chlorophyll (WOLFFI; FLOSS,

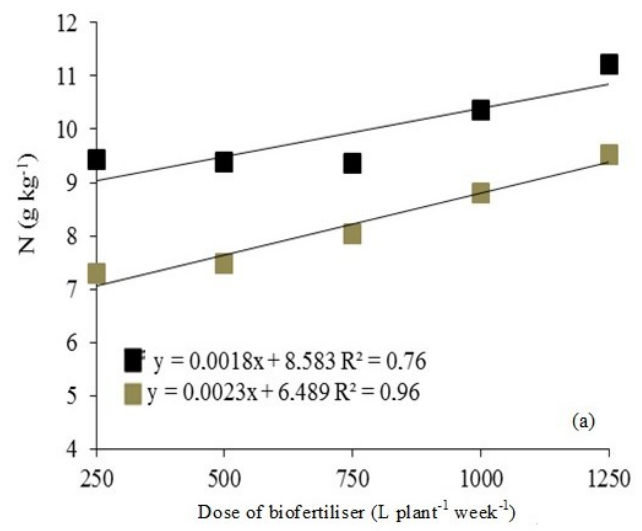

2008). Santos et al. (2014b), using biofertiliser from aerobic fermentation in the banana 'Pacovan', found higher values for roots $\left(9.8 \mathrm{~g} \mathrm{~kg}^{-1}\right)$ than in this study, but lower than that of anaerobic fermentation.

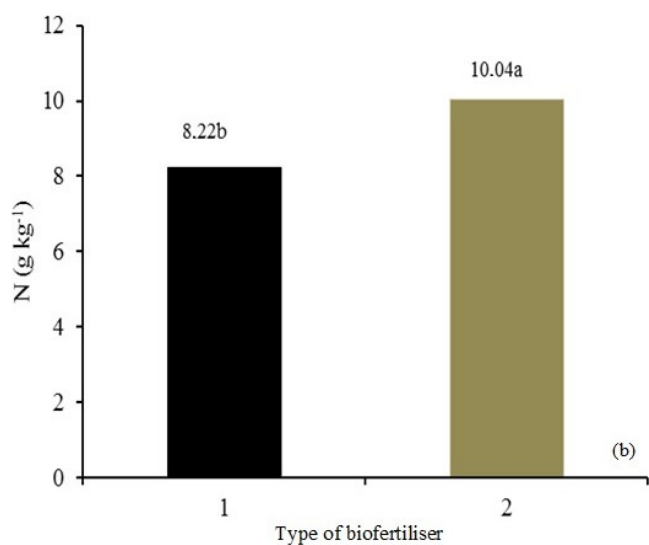

Figure 3. Levels of $\mathrm{N}$ in the leaves (a) and roots (b) of micropropagated plants of the banana 'Prata Catarina' under the application of aerobic $(\square)$ and anaerobic $(\square)$ biofertilisers.

Based on the result of the mean-value test (Figure $4 a$ ), it can be seen that the levels of $P$ in the leaves under the aerobic bovine biofertiliser (3.38 $\mathrm{g} \mathrm{kg}^{-1}$ ) were greater than those under the anaerobic biofertiliser $\left(2.93 \mathrm{~g} \mathrm{~kg}^{-1}\right)$.

The mean values obtained with the biofertilisers exceeded those considered satisfactory by Moreira and Fageria (2009), i.e., $1.59 \mathrm{~g} \mathrm{~kg}^{-1}$ in the banana 'Thap Maeo'. In contrast to the present study, Santos et al. (2014b), working under field conditions, found a leaf $P$ content of $1.4 \mathrm{~g} \mathrm{~kg}^{-1}$ in the banana 'Pacovan'. On the other hand, Cavalcante et al. (2010) obtained higher levels of phosphorus $\left(8.15 \mathrm{~g} \mathrm{~kg}^{-1}\right)$ when applying goat manure to the soil as an organic source during okra cultivation.

The value of $P$ in the leaves was $2.54 \mathrm{~g} \mathrm{~kg}^{-1}$ in the control and $3.34 \mathrm{~g} \mathrm{~kg}^{-1}$ under mineral fertilisation, whereas, in the roots, it was $1.32 \mathrm{~g} \mathrm{~kg}^{-1}$ under mineral fertilisation and $1.53 \mathrm{~g} \mathrm{~kg}^{-1}$ in the

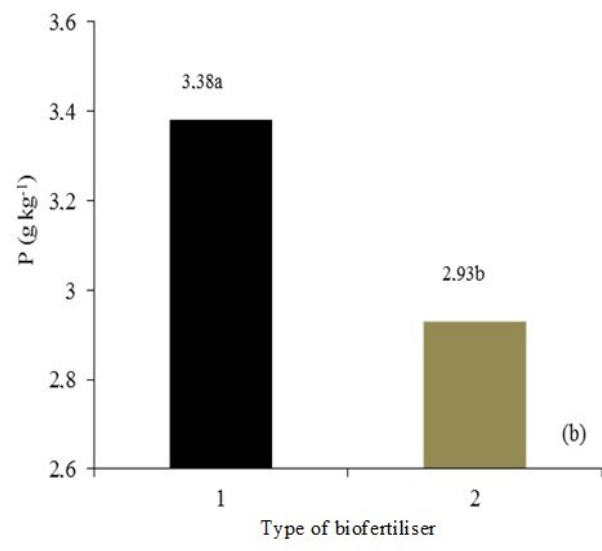

control. The different doses of bovine biofertiliser produced a linear increase in the levels of phosphorus in the roots (Figure $4 \mathrm{~b}$ ).

According to Dechen and Nachtigall (2007), in situations where the phosphorus supply to the soil and/or substrate increases from a state of deficiency to that of adequate availability, there is rapid formation, growth, and accumulation of roots in the plants.

It should be noted that phosphorus is an element that favours the development of root system in banana (FLORI; RESENDE, 2016). Results contrary to those of this study were reported by Santos et al. (2014b), who analysing the mineral element content of banana 'Pacovan' plants fertilised with biofertiliser. Those authors obtained a value of $1.1 \mathrm{~g} \mathrm{P} \mathrm{kg}^{-1}$ in the roots of banana plants grown under field conditions.

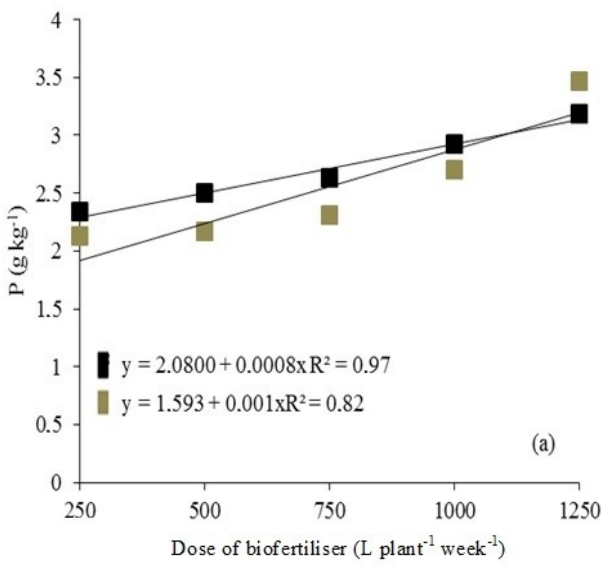

Figure 4. Levels of $\mathrm{P}$ in the leaves (a) and roots (b) of micropropagated plants of the banana 'Prata Catarina' under the application of aerobic $(\square)$ and anaerobic $(\square)$ biofertilisers. 
The value of $\mathrm{K}$ in the leaves was $39.4 \mathrm{~g} \mathrm{~kg}^{-1}$ in the control and $46.3 \mathrm{~g} \mathrm{~kg}^{-1}$ under mineral fertilisation, whereas, in the roots, it was $6.90 \mathrm{~g} \mathrm{~kg}^{-1}$ under mineral fertilisation and $11.45 \mathrm{~g} \mathrm{~kg}^{-1}$ in the control.

It can be seen in Figure 5 that with increasing doses of the aerobic and anaerobic biofertilisers, the levels of $\mathrm{K}$ in the leaves increased (A). The values are below the value of $26.37 \mathrm{~g} \mathrm{~kg}^{-1}$ recommended by Moreira and Fageria (2009). The opposite occurred in the roots (B), where the biofertiliser dose linearly inhibited the levels of $K$.

This effect might be related to $\mathrm{K}$ having great mobility inside the plants (FLORI; RESENDE, 2016). Another contributing factor for the reduction of $\mathrm{K}$ in the roots might be the high levels of $\mathrm{Na}$ present in the biofertilisers (Table 2).

Silva Júnior et al. (2012), studying the effects

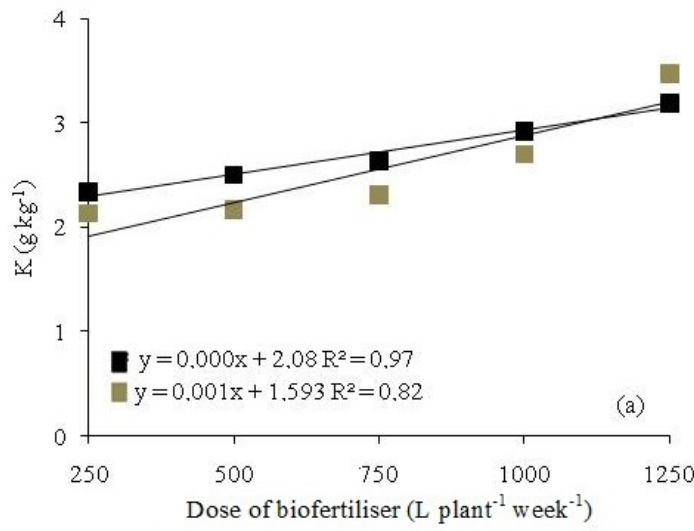

of $\mathrm{Na}^{+}$in micropropagated plantlets of the banana, found that this element preferentially accumulated in the roots, characterising a mechanism of compartmentalisation at the organ level, protecting the photosynthetic structure from the toxic effect of the cation.

$\mathrm{Na}$ also has an antagonistic effect to $\mathrm{K}$, as reported by Soares et al. (2011), when they observed a reduction in the $\mathrm{K}$ content with increasing $\mathrm{Na}$ content in two banana cultivars, Grand Naine and Dwarf Prata.

Such a result might be related to the large amount of $\mathrm{Mg}$ present in this organic input. Sousa et al. (2010) mention that the process of potassium absorption can be hampered by high $\mathrm{Mg}^{2+}$ concentration. Santos et al. (2014b), evaluating the application of biofertilisers in banana, obtained lower $\mathrm{K}$ levels than those in this study $\left(18.9 \mathrm{~g} \mathrm{~kg}^{-1}\right)$.

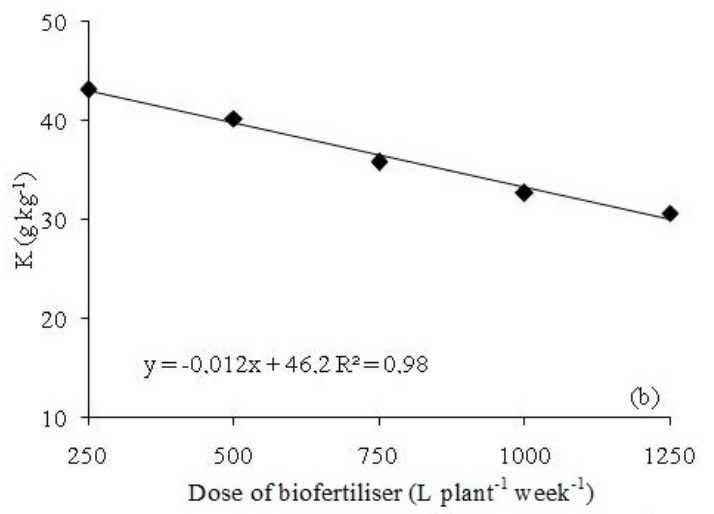

Figure 5. Levels of $\mathrm{K}$ in the leaves (a) and roots (b) of micropropagated plants of the banana 'Prata Catarina' under the application of aerobic ( $\square$ ) and anaerobic $(\square)$ biofertilisers.

The value of $\mathrm{Ca}$ in the leaves was $14.44 \mathrm{~g} \mathrm{~kg}^{-1}$ in the control and $16.39 \mathrm{~g} \mathrm{~kg}^{-1}$ under mineral fertilisation, whereas, in the roots, it was $19.55 \mathrm{~g} \mathrm{~kg}^{-1}$ under mineral fertilisation and $15.08 \mathrm{~g} \mathrm{~kg}^{-1}$ in the control.

It was found that quadratic polynomial model was the best fit for the data, with a maximum $\mathrm{Ca}$ content of $18.47 \mathrm{~g} \mathrm{~kg}^{-1}$ with a dose of $810 \mathrm{~L} \mathrm{plant}^{-1}$ week $^{-1}$ for the anaerobic biofertiliser, and $15.17 \mathrm{~g} \mathrm{~kg}^{-1}$ with a dose of $671 \mathrm{~L} \mathrm{plant}^{-1}$ week $^{-1}$ for the aerobic biofertiliser (Figure 6). The greater accumulation of calcium in the leaves is due to its role in maintaining a firm consistency of the organ with respect to the other organs.

The values for leaf $\mathrm{Ca}$ content for both aerobic and anaerobic biofertilisers are below the range considered suitable for leaves of the banana plant (MOREIRA; FAGERIA, 2009), where a value of $23.98 \mathrm{~g} \mathrm{~kg}^{-1}$ is considered satisfactory. This result might be related to the high $\mathrm{Na}$ content in the biofertilisers. Sousa et al. (2010) state that an excess of $\mathrm{Na}$ can cause $\mathrm{Ca}$ deficiency.

Contrary to that seen in the present study, Soares et al. (2011), working under field conditions, found a leaf Ca content of $43.07 \mathrm{~g} \mathrm{~kg}^{-1}$ in the Grand Naine banana cultivar. Working with a crop of sweet pepper fertilised with pig biofertiliser, Sediyama et al. (2014) found results similar to those in this study.

The value of $\mathrm{Mg}$ in the leaves was $1.66 \mathrm{~g} \mathrm{~kg}^{-1}$ in the control, and $2.35 \mathrm{~g} \mathrm{~kg}^{-1}$ under mineral fertilisation, whereas, in the roots, it was $2.24 \mathrm{~g} \mathrm{~kg}^{-1}$ under mineral fertilisation and $1.35 \mathrm{~g} \mathrm{~kg}^{-1}$ in the control.

The linear model was the best fit for $\mathrm{Mg}$ content (Figure 7). The values obtained with the biofertilisers were similar to those considered satisfactory by Moreira and Fageira (2009), of $2.5 \mathrm{~g} \mathrm{~kg}^{-1}$ in the Thap Maeo banana cultivar. The concentration of $\mathrm{Mg}$ in leaves of the banana plant might be reduced by a high concentration of $\mathrm{K}$, or via easy translocation in the plant (HOFFMANN et al., 2010). 


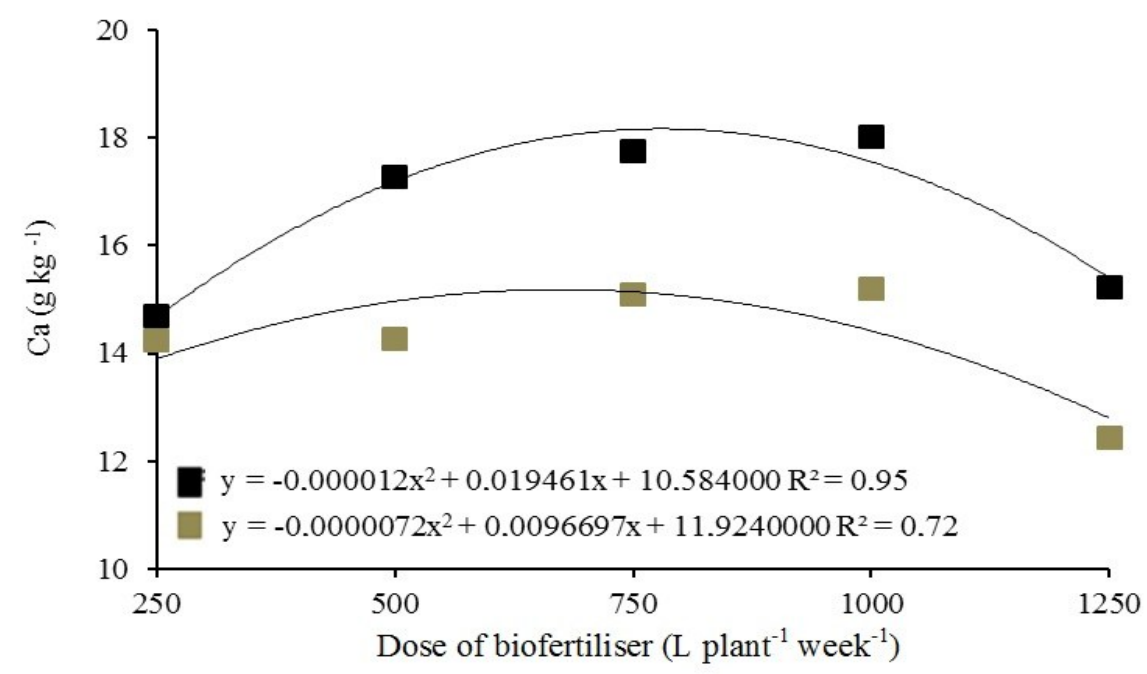

Figure 6. Levels of $\mathrm{Ca}$ in the leaves of micropropagated plants of the banana 'Prata Catarina' under the application of aerobic $(\square)$ and anaerobic $(\square)$ biofertilisers.

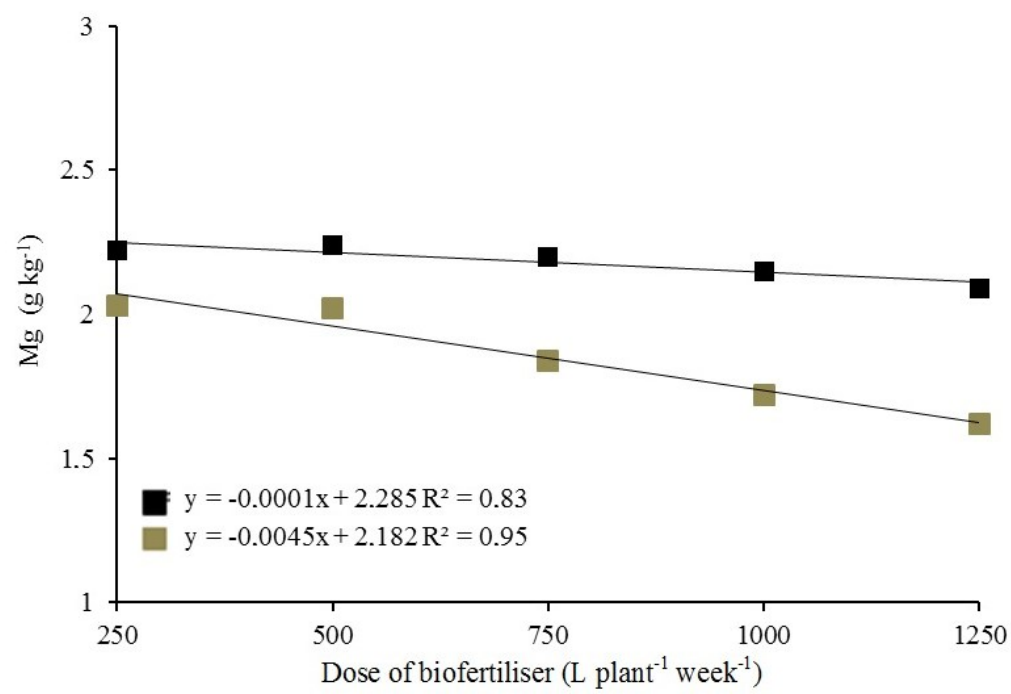

Figure 7. Levels of $\mathrm{Mg}$ in the leaves of micropropagated plants of the banana 'Prata Catarina' under the application of

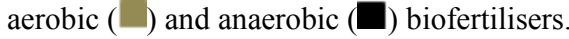

The reduction in $\mathrm{Mg}$ with increasing doses of biofertiliser is possibly related to the antagonistic effect of $\mathrm{K}$ and the toxic effect of $\mathrm{Na}$ present in the organic input. Soares et al. (2011), working under field conditions, found results opposite to those of the present study, when irrigating plants of the banana cultivar Grand Naine with moderately saline water. These authors found the value for $\mathrm{Mg}$ as $27.69 \mathrm{~g} \mathrm{~kg}^{-1}$.

This result differs from other studies that show an increase in leaf magnesium content, as reported by Damatto Júnior et al. (2011), when fertilising the Dwarf Prata banana cultivar, and by Sediyama et al. (2014), who fertilised a crop of sweet pepper with pig biofertiliser.

\section{CONCLUSION}

During the 90 days of acclimatization for the plants, the nutritional contribution of the bovine biofertiliser with anaerobic fermentation was greater in comparison with the biofertiliser with aerobic fermentation and the control; however, it was lower in comparison with the mineral fertiliser.

The 1000-mL dose of biofertiliser with anaerobic fermentation promotes greater dry weight accumulation in the leaves and roots of the banana 'Prata Catarina'.

The biofertiliser with anaerobic fermentation promotes higher levels of $\mathrm{N}, \mathrm{K}$, and $\mathrm{Ca}$ in the leaves, whereas the biofertiliser with aerobic fermentation promotes higher levels of $\mathrm{P}$ in the leaves and roots.

\section{REFERENCES}

BAALOUSHA, M.; HEINO, M. M.; LE COUSTUMER, B. K. Conformation and size of humic substances: effects of major cation concentration and type, $\mathrm{pH}$, salinity and residence 
time. Colloids and surfaces A: Physicochemical and Engineering Aspects, Amsterdam, v. 222, n. 12, p. 48-55, 2006.

BALDOTTO, L. E. B. et al. Desempenho do abacaxizeiro 'Vitória' em resposta aplicação de ácidos húmicos durante a aclimatação. Revista Brasileira de Ciência do Solo, Viçosa, v. 33, n. 4, p. 979-990, 2009.

BORGES, A. L.; SOUZA, L. S. Recomendações de calagem e adubação para bananeira. Cruz das Almas: Embrapa Mandioca e Fruticultura, 2010. 5 p. (Comunicado Técnico, 137).

CARVAlHO, A. C. P. P.; RODRIGUES, A. A. J.; SANTOS, E. O. Produção de mudas micropropagadas de bananeira. Fortaleza: Embrapa Agroindústria Tropical, 2012. 42 p. (Circular Técnica, 37).

CAVAlCANTE, L. F. et al. Teores foliares de macronutrientes em quiabeiro cultivado sob diferentes fontes e níveis de matéria orgânica. Semina: Ciências Agrárias, Londrina, v. 31, n. 1, p. 19-28, 2010.

CHICONATO, D. A. et al. Resposta da alface à aplicação de biofertilizante sob Dois níveis de irrigação. Bioscience Journal, Uberlândia, v. 29, n. 2, p. 392-399, 2013.

DAMATTO JUNIOR, E. R. et al. Alterações nos teores nutricionais foliares de bananeira 'Prata-Anã' adubada com composto orgânico em cinco ciclos de produção. Revista Brasileira de Fruticultura, Jaboticabal, Sup., p. 692-698, 2011.

DECHEN, A. R.; NACHTIGALL, G. R. Elementos requeridos à nutrição de plantas. In: NOVAIS, R. F. et al. (Eds.). Fertilidade do solo. Viçosa: Sociedade Brasileira de Ciência do Solo, 2007. p. 91-132.

FOOD AND AGRICULTURE ORGANIZATION OF THE UNITED NATIONS - FAO. FAOSTAT: production-crops. Disponível em: http:// faostat.fao.org/site/567/DesktopDefault.aspx? PageID=567\#ancor $>$. Acesso em: 07 jan. 2016 .

FERREIRA, D. F. Sisvar: a guide for its bootstrap procedures in multiple comparisons. Ciência e Agrotecnologia, Lavras, v. 38, n. 2, p. 109-112, 2014.

FLORI, J. E.; RESENDE, G. M. Soil chemical attributes and leaf nutrients of 'Pacovan' banana under two cover crops. Revista Caatinga, Mossoró, v. 29, n. 2, p. 290-295, 2016.

GARRUTI, D. S. et al. Aceitação de cultivares de bananas resistentes à Sigatoka Negra junto ao consumidor da região Nordeste do Brasil. Ciência Rural, Santa Maria, v. 42, n. 5, p. 948-954, 2012.

HOFFMANN, R. B. et al. Acúmulo de matéria seca, absorção e exportação de micronutrientes em variedades de bananeira sob irrigação. Ciência e Agrotecnologia, Lavras, v. 34, n. 3, p. 536-544, 2010

LIMA, J. D.; BELLICANTA, G. S.; MORAES, W. S. Uso de fertilizante organo-mineral fluído na aclimatação de mudas de bananeira micropropagadas. Revista Científica Eletrônica de Agronomia, Garça, v. 5, n. 9, p. 1-11, 2006.

MALAVOLTA, E. Manual de nutrição mineral de plantas. 1. ed. Piracicaba, SP: Editora Agronômica Ceres, 2006. $631 \mathrm{p}$.

MARTINS, A. N. et al. Aclimatação de mudas micropropagadas de bananeira 'Nanicão Williams' em diferentes substratos e fontes de nutrientes. Revista Brasileira Ciências Agrárias, Recife, v. 6, n. 1, p. $65-72,2011$.

MOREIRA, A.; FAGERIA, N. K. Repartição e remobilização de nutrientes na bananeira. Revista Brasileira de Fruticultura, Jaboticabal, v. 31, n. 2, p 574-581, 2009.

MURASHIGE, T.; SKOOG, F. A Revised medium for rapid growth and bioassays with tobacco tissue cultures. Physiologia Plantarum, Copenhagen, v. 15 , n. 3, p. 473-497, 1962

NOMURA, E. S. et al. Crescimento de mudas micropropagadas da bananeira cv. Nanicão em diferentes substratos e fontes de fertilizante. Acta Scientiarum Agronomy, Maringá, v. 30, n. 3, p. 359-363, 2008

NOMURA, E. S. et al. Aclimatização de mudas micropropagadas de bananeira 'Grand Naine' com aplicação de biofertilizantes em duas estações do ano. Revista Ceres, Viçosa, v. 59, n. 4, p. 518-529, 2012.

PEREIRA, G. A. et al. Controle de contaminantes em explantes de bananeira Grande Naine na micropropagação in vitro. Tecnologia \& Ciência Agropecuária, João Pessoa, v. 4, n. 2, p. 35-39, 2010

SAMPAIO, E. V. S. B.; OLIVEIRA, N. M. B.; NASCIMENTO, P. R. F. Eficiência da adubação orgânica com esterco bovino e com Egeria densa. Revista Brasileira Ciência do Solo, Viçosa, v. 31, n. 5, p. 995-1002, 2007. 
SANTOS, A. P. G. et al. Produtividade e qualidade de frutos do meloeiro em função de tipos e doses de biofertilizantes. Horticultura Brasileira, Brasília, v. 32, n. 4, p. 409-416, 2014a.

SANTOS, J. W. G. et al. Respostas da bananeira (Musa sp.), cultivar Pacovan em sistemas de manejo com aplicação de fertilizante mineral e biofertilizante. Revista Caatinga, Mossoró, v. 27, n. 4, p. 142-152, 2014b.

SENA, J. V. C. Aspectos da produção e mercado da banana no Nordeste. Fortaleza: Escritório Técnico de Estudos Econômicos do Nordeste ETENE, 2011. 7 p. (Informe Rural, 10).

SILVA, F. L. et al. Yield of common fig fertigated with bovine biofertilizer in the semiarid region of Ceará. Revista Caatinga, Mossoró, v. 29, n. 2, p. 425-434, 2016.

SILVA JÚNIOR, G. S. et al. Parâmetros biométricos, nutricionais e bioquímicos em cultivares e somaclones de bananeira submetidos à salinidade. Revista de Ciência, Tecnologia e Humanidades, Recife, v. 4, n. 1, p 11-36, 2012.

SEDIYAMA, M. A. N. et al. Nutrição e produtividade de plantas de pimentão colorido, adubadas com biofertilizante de suíno. Revista Brasileira de Engenharia Agrícola e Ambiental, Campina Grande, v. 18, n. 6, p. 588-594, 2014.

SOARES, F. A. L. et al. Acúmulo de matéria seca e distribuição de nutrientes em duas cultivares de bananeiras irrigadas com água moderadamente salina. Revista Brasileira Ciências Agrárias, Recife, v. 6, n. 2, p. 321-330, 2011.

SOUSA, G. G. et al. Nutrição mineral e extração de nutrientes de planta de milho irrigada com água salina. Revista Brasileira de Engenharia Agrícola e Ambiental, Campina Grande, v. 14, n. 11, p. 1143-1151, 2010.

TEDESCO, M. J. et al. Análises de solos, plantas e outros materiais. 2.ed. Porto Alegre: UFRGS, Departamento de Solos, Faculdade de Agronomia, 1995. 174 p. (Boletim técnico, 5)

VIANA, T. V. A. et al. Trocas gasosas e teores foliares de NPK em meloeiro adubado com biofertilizantes. Revista Brasileira de Ciências Agrárias, Recife, v. 8, n. 4, p. 595-601, 2013.

WOLFFI, W. M.; FLOSS, E. L. Correlação entre teores de nitrogênio e de clorofila na folha com o rendimento de grãos de aveia branca. Revista Ceres, Viçosa, v. 38, n. 6, p. 1510-1515, 2008. 